\title{
MENGENALKAN DAKWAH PADA ANAK USIA DINI
}

\author{
Siti Hikmah \\ Universitas Islam Negeri (UIN) Walisongo Semarang \\ Email: hikmahanas@yahoo.com
}

\begin{abstract}
One of the important parts relating to education for children is teaching da'wah since their early age, so that it becomes a habit for their life till they reach adulthood. Da'wah is regarded as a good process of education and it really should refer to the Islamic values which is implemented to children since early age. If this education process can run well, it would generate younger generations who have strong commitment. Introducing da'wah in early childhood requires extra patience to understand the child's condition; like the pra-formal operational stage of cognitive growth process, so that it requires easily understandable methods for children in its implementation. There are some methods to introduce da'wah for children; namely singing, role model, role playing, field trips, poetry, and speeches.

Salah satu bagian penting yang harus mendapatkan perhatian terkait dengan pendidikan yang diberikan sejak usia dini adalah mengajarkan dakwah pada anak sejak dini, sehingga dakwah sudah menjadi kebiasaan dan menjadi bagian hidup anak ketika dewasa. Dakwah dipandang sebagai proses pendidikan yang baik dan benar-benar harus mengacu pada nilai-nilai Islam yang diterapkan sedini mungkin kepada anak-anak. Apabila proses tersebut dapat berjalan dengan baik, maka akan muncul generasi muda yang memiliki komitmen yang kuat. Untuk mengenalkan dakwah pada anak usia dini membutuhkan kesabaran yang ekstra dengan memahami kondisi anak misalnya proses pertumbuhan kognitifnya yang masih dalam tahap pra operasional formal, sehingga membutuhkan metode dalam aplikasinya yang mudah difahami anak. Metode dalam mengenalkan dakwah pada anak melalui bernyanyi, tauladan, bermain peran, karya wisata, bersyair, dan berpidato.
\end{abstract}

Keywords: da'wah (propaganda), early childhood, methods 


\section{A. Pendahuluan}

Anak merupakan investasi yang sangat penting bagi penyiapan sumber daya manusia (SDM) di masa depan. Dalam rangka mempersiapakan SDM yang berkualitas untuk masa depan, pendidikan merupakan salah satu hal yang penting untuk diberikan sejak usia dini. Pendidikan merupakan investasi masa depan yang diyakini dapat memperbaiki kehidupan suatu bangsa. Memberikan perhatian yang lebih kepada anak usia dini untuk mendapatkan pendidikan merupakan salah satu langkah yang tepat untuk menyiapkan generasi unggul yang akan meneruskan perjuangan bangsa.

Usia dini merupakan masa keemasan (golden age) yang hanya terjadi satu kali dalam perkembangan kehidupan manusia. Masa ini sekaligus merupakan masa yang kritis dalam perkembangan anak. Jika pada masa ini anak kurang mendapat perhatian dalam hal pendidikan, perawatan, pengasuhan dan layanan kesehatan serta kebutuhan gizinya dikhawatirkan anak tidak dapat tumbuh dan berkembang secara optimal.

Salah satu bagian penting yang harus mendapatkan perhatian terkait dengan pendidikan yang diberikan sejak usia dini adalah mengajarkan dakwah pada anak sejak dini, sehingga dakwah sudah menjadi kebiasaan dan menjadi bagian hidup anak ketika dewasa. Dakwah dipandang sebagai proses pendidikan yang baik dan benar-benar harus mengacu pada nilainilai Islam yang diterapkan sedini mungkin kepada anak-anak. Apabila proses tersebut dapat berjalan dengan baik, maka akan muncul generasi muda yang memiliki komitmen yang kuat.

Pengembangan dakwah dimaksudkan agar ajaran Islam secara keseluruhan meresapi kehidupan manusia sehingga mampu memecahkan segala masalah kehidupannya, pemenuhan kebutuhannya yang sesuai dengan ridha Allah swt. Dengan demikian, dakwah dipandang sebagai proses pendidikan individu dan masyarakat sekaligus proses pembangunan itu sendiri. Namun dengan keterbatasan anak, bagaimana mengenalkan dakwah pada anak usia dini ? bagaimana metode dalam mengenalkan dakwah pada anak?

\section{B. Pentingnya Mengenalkan Dakwah pada Anak}

Allah telah memberikan tanggung jawab besar kepada orang tua terkait pendidikan anak-anak. Sebagaimana hadis nabi berikut ini :Dari Abdullah bin Umar radhiallahu anhu, dia berkata, "Aku mendengar Rasulullah shallallahu alaihi wa sallam bersabda, "Semua kalian adalah 
pemimpin dan kalian akan ditanya tentang orang-orang yang kalian pimpin. Kepala negara adalah pemimpin, dan akan ditanya tentang kepemimpinannya, seorang bapak pemimpin dalam keluarganya, dan dia akan ditanya tentang yang dipimpinnya. Seorang ibu pemimpin di rumah suaminya." 1

Kecilnya usia Abdullah bin Abbas tidak mengalangi Rasulullah shallallahu alaihi wa sallam untuk menyampaikan kepadanya ajaran-ajaran tauhid dan aqidah.Dari Ibnu Abbas, dia berkata, "Aku dahulu suatu hari berada di belakang Rasulullah shallallahu alaihi wa sallam, lalu beliau berkata,

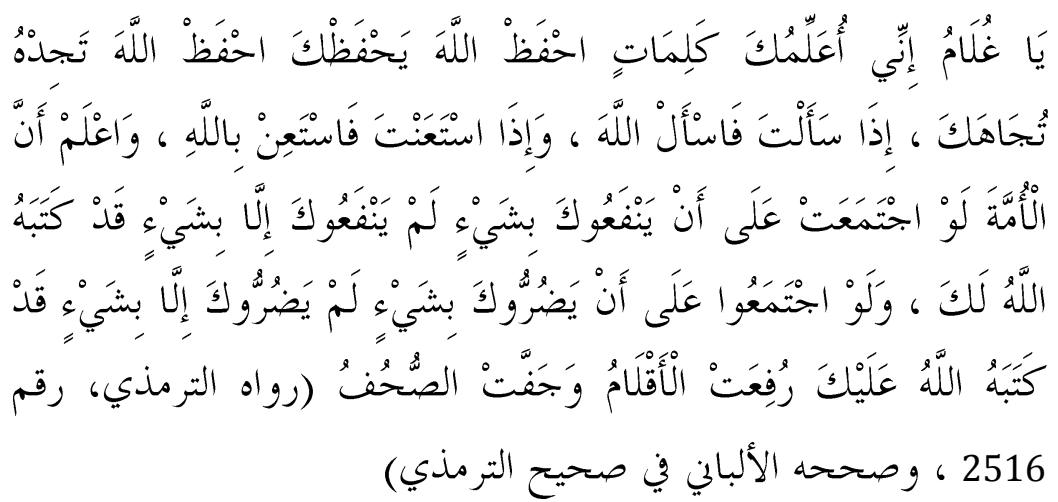

"Wahai ananda, aku ajarkan kepadamu beberapa pelajaran; Jagalah Allah, Dia akan menjaga-Mu. Jagalah Allah, engkau akan dapatkan Dia berada di hadapan-Mu. Jika engkau meminta, maka mintalah kepada Allah. Jika engkau minta pertolongan, maka mintalah pertolongan kepada Allah. Ketahuilah, sesungguhnya umat ini, jika mereka berkumpul untuk mendatangkan suatu manfaat untukmu, niscaya mereka tidak dapat mendapatkan manfaat untukmu kecuali apa yang Allah tetapkan untukmu. Dan seandainya mereka berkumpul untuk mendatangkan bahaya untukmu, niscaya mereka tidak dapat mendatangkan suatupun bahwa untukmu selain apa yang telah Allah tetapkan untukmu. Pena telah diangkat dan catatan telah kering."

1 An Naisâburi, Muslim bin Hajjâj, Shahih Muslim, (Bairut: Dar Ihya' Turats al-Arabi, 1991), hlm. 1829. 
Masa usia dini merupakan fase dasar untuk tumbuhnya kemandirian, belajar untuk berpartisipasi, kreatif, imajinatif dan mampu berinteraksi. Hal ini senada dengan ungkapan Ihat (2003) bahwa perkembangan intelegensi, kepribadian dan perilaku sosial pada manusia terjadi paling cepat pada usia dini, bahkan menurut Bloom (1984) bahwa separuh dari semua potensi intelektual sudah terjadi pada umur empat tahun.Disamping itu anak usia dini memori otaknya masih bersih belum banyak isinya, sangat mudah bagi anak untuk menghafal ayat suci al-Qur'an, hadits nabi dan lebih mudah membentuk kebiasaan dakwah².

Selain itu, perkembangan zaman yang semakin modern, mempengaruhi nilai keagamaan anak ketika dewasa.Tantangan dakwah kedepan lebih berat, karena itu perlu diperkenalkan dakwah sejak anak usia dini, agar anak ketika dewasa sudah terbiasa dengan dakwah yang sudah menjadi bagian dari kehidupannya. Secara evolusi, obyek dakwah mengalami perkembangan ke arah yang lebih tinggi sesuai dengan tingkat kemajuan dan intelektual. Bahkan seharusnya seirama dengan tingkat perkembangan ilmu pengetahuan dan teknologi.

\section{Mengajarkan Dakwah pada Anak Usia Dini}

Masalah dakwah dalam Islam sama umurnya dengan Islam sebagai agama Allah Swt, agama Islam yang dibawa oleh Nabi Muhammad Saw, pada dasarnya disebarluaskan dengan jalan dakwah. Dakwah ini dijalankan Nabi dengan cara lemah lembut. Melalui dakwah orang-orang Arab Jahiliah diharapkan secara sukarela menjadi seorang muslim. Menjadi seorang muslim hendaknya didasarkan kepada penerimaan dan kesadaran, bukan dengan paksaan atau tekanan.

Pendidikan untuk anak usia dini (0-8 tahun) merupakan pendidikan yang memiliki karakteristik berbeda dengan anak usia lain, sehingga pendidikannya pun perlu dipandang sebagai sesuatu yang dikhususkan. Dalam mengajarkan dakwah kepada anak, tidak boleh dilakukan dengan pemaksaan namun disesuaikan dengan perkembangan kognitif anak. Anak usia dini adalah anak yang sedang dalam tahap perkembangan pra operasional kongkrit, sedangkan materi dakwah bersifat nilai-nilai

2 Dalam banyak kasus, mengajarkan hafalan pada anak usia dini lebih mudah dibanding dengan orang dewasa, misalnya di TPQ Al-Hikmah mengajarkan hafalan yasin pada anak usia 5-7 tahun lebi cepat dibanding dengan anak remaja, apalagi dengan orang dewasa. Selain itu mengajarkan dakwah dalam bentuk hafalan pidato kepada anak 5-7 lebih cepat dibanding dengan anak usia remaja. Pada anak usia dini lebih mudah bagi mereka untuk mengatasi nervous panggung dibanding ketika sudah remaja. 
ketuhanan, moral merupakan konsep-konsep yang abstrak, sehingga dalam hal ini anak belum dapat dengan serta merta menerima apa yang diajarkan guru atau orang tua yang sifatnya abstrak secara cepat.

Pendidikan anak usia dini bertujuan membimbing dan mengembangkan potensi setiap anak agar dapat berkembang secara optimal sesuai tipe kecerdasannya. Oleh karena itu pendidik atau guru harus memahami kebutuhan khusus atau kebutuhan individual anak. Akan tetapi, perlu disadari pula bahwa ada faktor-faktor yang sulit atau tidak dapat dirubah dalam diri anak yaitu faktor genetis. Karena itulah pendidikan anak usia dini diarahkan untuk memfasilitasi setiap anak dengan lingkungan dan bimbingan belajar yang tepat agar anak dapat berkembang sesuai kapasitas genetisnya.

Anak usia dini dipandang sebagai individu yang baru mulai mengenal dunia. Ia belum mengetahui tata krama, sopan santun, aturan, norma, etika, dan berbagai hal lain yang terkait dengan kehidupan duniawi. Usia dini merupakan masa bagi seorang anak untuk belajar berkomunikasi dengan orang lain serta memahaminya. Oleh karena itu seorang anak perlu dibimbing agar mampu memahami berbagai hal tentang kehidupan dunia dan segala isinya.

Beberapa upaya yang diperlukan anak usia dini dalam mengenalkan dakwah. Adalah sebagai berikut : Pertama membiasakan membaca alQur'an sejak anak didalam kandungan, berdoa kepada Allah semoga mereka Allah memberikan petunjuk dan taufiq, do'a orang tua merupakan sebab yang sangat besar bagi kebaikan dan hidayahmenanamkan nilai-nilai tauhidullah (keesaan Allah) sejak awal. Ma'rifatullah (mengenal Allah) adalah tema pertama yang harus diajarkan kepada anak-anak, tentu dengan bahasa dan contoh-contoh yang sederhana. Agar terpatri dalam ruang pikirnya, siapa penciptanya, siapa pemberi rizki, siapa pengatur hidup, siapa penguasa alam, siapa yang pantas disembah, siapa yang menghidupkan dan mematikan, dll. Ajak anak untuk mengenal Alloh Swt Maha Pencipta dengan menceritakan menggunakan alat peraga baik gambar atau memperhatikan keadaan di lingkungan sekitar seperti burung, ular, serta hewan atau lingkungan lainnya, atau tentang fakta penciptaan organ tubuh seperti mata, hidung, telinga, dll.

Kedua, menanamkan pendidikan ma'rifaturrasul (mengenal Rasulullah) sejak dini, agar ia memiliki teladan yang mampu menjadi pemandu hidupnya, dan tidak salah pilih teladan. Apalagi, saat ini banyak para artis, atau tokoh-tokoh khayalan dan rekaan yang mencoba merebut hati para anak-anak kita, baik cerita rakyat seperti Gatot Kaca atau dari Barat seperti Superman, Batman, Satria Baja Hitam, Power Rangers. 
Sekadar tahu tokoh-tokoh ini tidak ada masalah, namun jadi masalah jika anak menjadikan mereka sebagai teladan hidupnya, dan melupakan Rasulullah Shallallahu 'Alaihi wa Sallam.

Ketiga, menanamkan tarbiyah akhlaqiyah wa sulukiyah ${ }^{3}$ (pembinaan akhlak dan perilaku) sejak dini agar anak menghormati orang tua dan yang lebih tua, atau menyayanyi yang lebih muda. Agar anak tahu adab makan, minum, berjalan, berpakaian, dan berbicara, serta adab-adab lainnya. Supaya mereka menyayangi sahabat dan memaafkan musuh. Ibnu Qayim rahimahullah berkata, "Siapa yang lalai dalam mengajarkan anaknya sesuatu yang bermanfaat dan membiarkannya begitu saja, maka dia telah melakukan sesuatu yang sangat buruk terhadapnya. Kebanyakan anakanak sebab kerusakannya bersumber dari orang tuanya yang melalaikannya dan mengabaikan pendidikan agamanya. Mereka telah menyia-nyiakannya di masa kecil, sehingga mereka tidak berbuat sesuatu yang bermanfaat untuk dirinya dan tidak juga mendatangkan manfaat untuk orang tuanya ketika telah besar."

Keempat, memperkenalkan dengan tokoh-tokoh Islam, mulai para sahabat nabi, para Imam dan ulama, para pahlawan dan mujahidin Islam, baik dalam atau luar negeri. Bukan justru memperkenalkan mereka dengan bintang film, penyanyi, pemain sepak bola, atau penghibur yang membuatnya jauh dari Allah dan kewajiban-kewajiban agama.

Kelima, mengajarkan anak untuk berdoa sebelum melakukan aktivitas, sampaikan kepada mereka bahwa berdoa berarti memohon pertolongan dan kelancaran kepada Allah SWT atas aktivitas yang hendak dijalankan. Jangan lupa sesudahnya mengucapkan kalimat hamdalah sebagai salah satu wujud kesyukuran. Sebelum memulai seluruh aktivitas yang bersentuhan dengan proses pembelajaran usahakan melakukan Kebulatan Tekad Pagi Hari. Hal ini merupakan pengganti salam penghormatan kepada ilmu, biasakan anak membaca kebulatan tekad sebelum pelajaran dimulai :"Rodhiitu billahi robba wa bil islami diinaa wabimuhammadin nabiyya wa rosuula"' Kami rela Alloh sebagai Rabb kami, Islam sebagai agama kami, dan Muhammad sebagai Nabi dan Rasul kami."

Keenam, bila melarang anak, diupayakan untuk tidak mengancamnya dengan dosa, neraka dan hal-hal menakutkan lainnya. Pola pikir anak yang konkret operasional cenderung sulit untuk memahami makna dosa, neraka, dsb. Cukup berikan mereka penjelasan konkret yang dapat diterima oleh pikirannya, misalnya untuk melarang anak mencuri, cukup berikan mereka

\footnotetext{
3 Tim Kajian Dakwah Al Hikmah, Mengenalkan Allah pada Anak, www.alhikmah.ac.id
} 
penjelasan bahwa hal tersebut dapat menyakiti orang lain karena berarti mengambil hak yang bukan miliknya.

Ketujuh, pabila anak melakukan kesalahan, bantu mereka untuk menemukan jalan dalam memperbaiki kesalahannya, tanpa harus mengancam dengan dosa, neraka dan sebagainya, karena hal tersebut akan membuat persepsi anak negatif terhadap Islam. Ketujuh, menyertakan anak saat menjalankan ibadah sehari-hari, seperti sholat berjamaah, kegiatan pengajian, dsb. Jelaskan pula hikmah yang bisa mereka dapatkan dari ibadah yang di jalankan. Dengan demikian, mereka akan semakin akrab dengan aktivitas keagamaan.

Kedelapan, dalam memilih hiburan, diupayakan untuk memberikan anak tayangan-tayangan yang tidak merusak aqidah. Hendaknya dirumah sering diperdengarkan ayat-ayat Allah, lantunan ayat suci Al Qur'an baik dibaca sendiri oleh orang tua, atau melalui kaset-kaset muratal. Ini lebih baik dan sangat baik demi keberkahan rumah dan turunnya rahmat Allah. Paling tidak, lagu anak-anak / lagu islami yang syairnya mendidik juga dapat kita perdengarkan.

Kesembilan, menyediakan buku-buku bacaan yang mendidik, yang mampu menambah pengetahuan agama dan akademik, serta iman mereka. Seperti buku-buku kisah tentang para nabi, sahabat, atau buku-buku doa sederhana, hadits-hadits, atau majalah Islam anak-anak dengan banyak gambar sehingga anak tertarik untuk membacanya serta mendampingi anak untuk membantu memahaminya, sebagaimana mendampingi anak ketika mereka menonton televisi agar bisa menjauhi tontonan yang tidak pantas. (Sebaiknya mencegah anak dari televisi, hingga saatnya mereka bisa membedakan mana baik mana buruk)Man syabba fii syai'iin syaaba 'alaih (Barang siapa yang dididik dengan sesuatu, maka sesuatu itulah yang akan membentuk dirinya hingga dewasa nanti)

Kesepuluh, memasukkan mereka ke sekolah-sekolah Islam. Hal ini dimaksudkan agar anak sejak dini berkumpul dengan orang yang berakhlak dan istiqomah agar dapat memberikan pengaruh dan menjadi teladan bagi anak-anak untuk komitmen dengan agama atau berpedoman dengan syariat serta dalam bersikap terhadap orang tua.

Rasulullah shallallahu alaihi wa sallam bersabda,

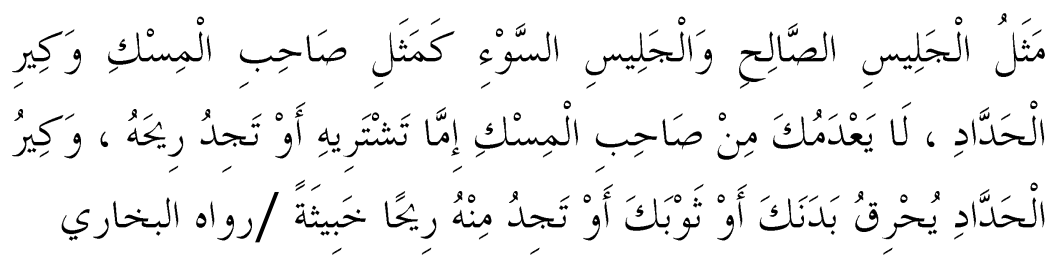


Perumpamaan teman yang saleh dan teman yang buruk, seperti penjual minyak wangi dan pandai besi. Pada penjual minyak wangi, anda akan dapat membelinya atau mendapatkan wangi harum. Sedangkan terhadap pandai besi, badan atau baju anda akan terkena percikannya atau anda akan mendapatkan aroma tidak sedap. ${ }^{4}$

Sebelas, mengenalkan anak dengan bahasa Arab dan menumbuhkan rasa cinta terhadapnya. Karena bahasa Arab merupakah konci untuk memahami dan mencintai Islam serta pintu awal dalam memahami makna al-Qur'an dan hadits. Disamping itu diperlukan sesering mungkin mengajak anak dalam kegiatan keagamaan baik di masjid maupun ditempat umum agar anak terbiasa dengan kegiatan dakwah.

\section{Metode Mengenalkan Dakwah pada Anak}

Dalam membimbing dan mengembangkan potensi anak usia dini perlu memilih metode yang tepat. Pemilihan metode yang dilakukan pendidik atau guru semestinya dilandasi alasan yang kuat dan faktor-faktor pendukungnya seperti karakteristik tujuan kegiatan dan karakteristik anak yang diajar. Karakteristik tujuan adalah pengambangan kognitif, pengembangan kreativitas, pengembangan bahasa, pengembangan emosi, pengembangan motorik, dan pengembangan nilai serta pengembangan sikap dan perilaku.

Untuk mengembangkan nilai dan sikap anak dapat dipergunakan metode-metode yang memungkinkan terbentuknya kebiasaan-kebiasaan yang didasari oleh nilai-nilai agama dan moralitas agar anak dapat menjalani kehidupan sesuai dengan norma yang berlaku di masyarakat.Setiap guru atau orang tua akan menggunakan metode sesuai dengan gaya dalam melaksanakan kegiatan. Tetapi bahwa mengenalkan dakwah pada anak usia dini memiliki cara yang khas. Oleh karena itu ada metode-metode yang lebih sesuai bagi anak dibandingkan dengan metodemetode lain. Misalnya saja guru atau orang tua akan kesulitan jika menggunakan metode ceramah. Hal ini karenakan metode ceramah membuat anak bosan, dan sulit untuk memahaminya serta anak usia dini sulit untuk diajak berfikir konsentrasi pada suatu hal atau topik.

Orang akan segera menyadari bahwa metode ceramah tidak sesuai dan tidak banyak berarti apabila diterapkan untuk anak usia dini. Metode-

${ }^{4}$ An Naisâburi, Muslim bin Hajjâj, Op.Cit, hlm. 2628 
metode yang memungkinkan anak dapat melakukan hubungan atau sosialisasi dengan yang lain akan lebih sesuai dengan kebutuhan dan minat anak. Melalui kedekatan hubungan guru dan anak, seorang guru atau orang tua akan dapat mengembangkan kekuatan pendidik yang sangat penting5.

Dalam mengenalkandakwah pada anak usia dinibanyak metode yang dapat digunakan oleh guru atau orang tua. Namun sebelum memilih dan menerapkan metode yang ada perlu diketahui bahwa guru atau pendidik harus memahami metode yang akan dipakai, karena ini akan berpengaruh terhadap optimal tidaknya keberhasilan dalam penanaman pengenalan dakwah pada anak. Metode dalam pengenalan dakwah kepada anak usia dini sangatlah bervariasi, diantaranya bercerita, bernyanyi, bermain, bersajak dan karya wisata. Masing-masing metode mempunyai kelemahan dan kelebihan. Penggunaan salah satu metode penanaman dakwah yang dipilih tentunya disesuaikan dengan kondisi sekolah atau kemampuan seorang guru dalam menerapkannya. Penjelasan lebih rinci masing-masing metode tersebut sebagai berikut:

Pertama, metode bercerita. Bercerita dapat dijadikan metode untuk menyampaikan nilai-nilai yang berlaku dalam masyarakat ${ }^{6}$. Dalam cerita atau dongeng dapat ditanamkan berbagai macam nilai moral, nilai ketuhanan, nilai sosial, nilai budaya, dan sebagainya. Ketika bercerita seorang guru juga dapat menggunakan alat peraga untuk mengatasi keterbatasan anak yang belum mampu berpikir secara abstrak. Alat peraga yang dapat digunakan antara lain, boneka, tanaman, benda-benda tiruan, dan lain-lain. Selain itu guru juga bisa memanfaatkan kemampuan olah vokal yang dimiliknya untuk membuat cerita itu lebih hidup, sehingga lebih menarik perhatian siswa.

Metode cerita akan sangat efektif dan diingat terus oleh anak ketika cerita tersebut diaplikasikan lansung oleh guru ketika menghadapi anak dengan kasus yang sama dengan judul cerita guru . Misalnya anak suka marah-marah, diingatkan dengan cerita harimau yang marah sama kancil, dan kancil bilang sama harimau "la tahthob walakal jannah" janganlah engkau marah surga bagimu". Hadits tersebut diulang terus menerus sampai anak menghafalnya, sehingga ketika ada teman sekolah atau

5 Moeslichatoen, R, Metode Pengajaran di Taman Kanak-Kana,. (Jakarta: Rineka Ciipta, 1999), hlm.7.

6 Otib Satibi Hidayat, Metode Pengembangan Moral dan Nilai-Nilai Agama,(Jakarta: Universitas Terbuka, 2000), hlm. 4.12. 
anggota keluarganya yang marah, anak bisa lansung bilang la tahthob walakal jannah". ${ }^{7}$

Kedua, metode bernyanyi. Metode bernyanyi adalah suatu pendekatan pembelajaran secara nyata yang mampu membuat anak senang dan bergembira. Anak diarahkan pada situasi dan kondisi psikis untuk membangun jiwa yang bahagia, senang menikmati keindahan, mengembangkan rasa melalui ungkapan kata dan nada. Pesan-pesan pendidikan berupa nilai ketuhanan dan moral yang dikenalkan kepada anak tentunya tidak mudah untuk diterima dan dipahami secara baik. Anak tidak dapat disamakan dengan orang dewasa. Anak merupakan pribadi yang memiliki keunikan tersendiri. Pola pikir dan kedewasaan seorang anak dalam menentukan sikap dan perilakunya juga masih jauh dibandingkan dengan orang dewasa. Anak tidak cocok hanya dikenalkan tentang nilai dan moral melalui ceramah atau tanya jawab saja. Misalnya mengenalkan tentang rukun islam atau rukun iman, dan doa melalui lagu. Melalui menyanyi yang diulang-ulang anak akan lebih mudah menerima materidan mengingatnya untuk bisa diaplikasikan dalam kehidupan seharihari serta mengajak orang lain untuk melakukan hal yang sama sebagaimana dengan dirinya. ${ }^{8}$

Ketiga, metode bersajak atau syair. Pendekatan pembelajaran melalui kegiatan membaca sajak merupakan salah satu kegiatan yang akan menimbulkan rasa senang, gembira, dan bahagia pada diri anak. Secara psikologis anak usia dini sangat haus dengan dorongan rasa ingin tahu, ingin mencoba segala sesuatu, dan ingin melakukan sesuatu yang belum pernah dialami atau dilakukannya.

Melalui metode sajak guru bisa menanamkan nilai-nilai moral kepada anak. Sajak ini merupakan metode yang juga membuat anak merasa senang, gembira dan bahagia. Melalui sajak anak dapat dibawa ke dalam suasana indah, halus, dan menghargai arti sebuah seni. Disamping itu anak juga bisa dibawa untuk menghargai makna dari untaian kalimat yang ada dalam sajak itu. Secara nilai moral, melalui sajak anak akan memiliki kemampuan untuk menghargai perasaan, karya serta keberanian untuk mengungkap sesuatu melalui sajak sederhana9.

7 Hal ini sudah dipraktekkan oleh siswa RA Al-Hikmah Wanutunggal Godong Grobogan, salah satu orang tua siswa yang bernama rahmah bercerita bahwa ketika marahmarah kepada anaknya, anak tersebut mengatakan "mae, marah-marah terus, la tahthob walakal jannah" janganlah engkau marah surga bagimu, sehingga orang tuanya menjadi terkekeh tidak jadi marah.

${ }^{8}$ Sebagaimana cerita orang luluk siswa RA Al-hikmah, "bu, sudah berdoa belum masuk kamar mandinya, nanti waktu kita mandi diintip syetan lho, berdoa dulu bu".

${ }^{9}$ Ibid, hlm. 4.29. 
Keempat, metode karyawisata. Metode karya wisata bertujuan untuk mengembangkan aspek perkembangan anak usia dini yang sesuai dengan kebutuhannya. Misalnya pengembangan aspek kognitif, bahasa, kreativitas, emosi, kehidupan bermasyarakat, dan penghargaan pada karya atau jasa orang lain. Tujuan berkarya wisata ini perlu dihubungkan dengan tematema yang sesuai dengan pengembangan aspek perkembangan anak usia dini. Tema yang sesuai adalah kebesaran Allah atas penciptaan dunia serta isinya yang meliputi binatang, kehidupan desa dan kota, pesisir, dan pegunungan, bungah dll.

Kelima, pembiasaan dalam berperilaku. Kurikulum yang berlaku di RA terkait dengan penanaman moral, lebih banyak dilakukan melalui pembiasaan-pembiasaan tingkah laku dalam proses pembelajaran. Ini dapat dilihat misalnya, pada berdoa sebelum dan sesudah belajar, berdoa sebelum makan dan minum, mengucap salam kepada guru dan teman, merapikan mainan setelah belajar, berbaris sebelum masuk kelas dan sebagainya. Pembiasaan ini hendaknya dilakukan secara konsisten. Jika anak melanggar segera diberi peringatan.

Keenam, metode bermain. Dalam bermain ternyata banyak sekali terkandung nilai dakwah, diantaranya nilai moral untuk mau mengalah, mau kerjasama, jujur, tolong menolong, budaya antri, menghormati teman. Nilai moral mau mengalah terjadi manakala siswa mau mengalah terhadap teman lainnya yang lebih membutuhkan untuk satu jenis mainan. Pengertian dan pemahaman terhadap nilai moral mau menerima kekalahan atau mengalah adalah salah satu hal yang harus ditanamkan sejak dini. Seringkali terjadi sikap moral tidak terpuji seperti perusakan dan tindakan anarkis lainnya yang dilakukan oleh oknum tertentu ketika ia kalah dalam suatu persaingan, misalnya dalam pemilihan kepala desa, bupati, gubernur, atau bahkan dalam pemilihan presiden. Oleh karena itu betapa penting untuk menanamkan nilai moral untuk mau menerima kekalahan sejak usia dini.

Ketujuh, metode outbond. Metode outbond merupakan suatu kegiatan yang memungkinkan anak untuk bersatu dengan alam. Melalui kegiatan outbond siswa alan dengan leluasa menikmati segala bentuk tanaman, hewan, dan mahluk ciptaan Allah yang lain. Cara ini dilakukan agar anak tidak hanya memahami apa yang diceritakan atau dituturkan oleh guru atau pendidik di dalam kelas. Melainkan mereka diajak langsung melihat atau memperhatikan sesuatu yang sebelumnya pernah diceritakan di dalam kelas, sehingga apa yang terjadi di kelas akan ada sinkronisasi dengan apa yang tampak di lapangan atau alam terbuka. 
Kedelapan, bermain peran. Bermain peran merupakan salah satu metode yang digunakan dalam mengenalkan dakwah kepada anak usia dini. Dengan bermain peran anak akan mempunyai kesadaran merasakan jika ia menjadiseseorang yang dia perankan dalam kegiatan bermain peran. Misalnya tema bermain peran tentang kasih sayang dalam keluarga. Anak akan merasakan bagaimana seorang ayah harus menyayangi anggota keluarga, bagaimana seorang ibu harus menyayangi keluarga, begitu juga bagaimana dengan anak-anaknya.

Kesembilan, metode diskusi. Diskusi yang dimaksud di sini adalah mendiskusikan tentang suatu peristiwa. Biasanya dilakukan dengan cara siswa diminta untuk memperhatikan sebuah tayangan dari CD, kemudian setelah selesai siswa diajak berdiskusi dengan guru tentang isi tayangan CD tersebut. Isi diskusinya antara lain mengapa hal tersebut dilakukan, mengapa anak itu dikatakan baik, mengapa harus menyayangi dan sebagainya.

Kesepuluh, metode teladan. Guru moral yang ideal adalah mereka yang dapat menempatkan dirinya sebagai fasilitator, pemimpin, orang tua dan bahkan tempat menyandarkan kepercayaan, serta membantu orang lain dalam melakukan refleksi. Guru hendaknya menjadi figur yang dapat dicontoh dalam bertingkah laku oleh siswanya. Secara kodrati manusia merupakan makhluk peniru atau suka melakukan hal yang sama terhadap sesuatu yang dilihat. Apalagi anak-anak, ia akan senantiasa dan sangat mudah meniru sesuatu yang baru dan belum pernah dikenalnya, baik itu perilaku maupun ucapan orang lain.

Kesebelas, mengajarkan anak menghafal pidato dalam durasi yang tidak lebih dari 5 menit dengan bahasa dan gaya khas anak. Bagi anak yang mempunyai daya ingat tinggi, akan dengan mudah dan cepat untuk menghafal materi pidato, asal tidak dikenalkan dengan ancaman dan paksaan $^{10}$.

\section{E. Kesimpulan}

Masalah dakwah dalam Islam sama umurnya dengan Islam sebagai agama Allah Swt, agama Islam yang dibawa oleh Nabi Muhammad Saw, pada dasarnya disebarluaskan dengan jalan dakwah. Dakwah ini dijalankan Nabi dengan cara lemah lembut. Memang melalui dakwah orang-orang

10 Dalam beberapa kasus di RA Al-Hikmah Wanutunggal Godong Grobogan, 30 persen anak usia dini bisa berdakwah melalui pidato dalam acara keagamaan baik dimasjid maupun dimasyarakat. Mereka melakukan pidato berdasarkan hafalan teks yang dibuat oleh guru dan dihafalkan dengan satu minggu. 
Arab Jahiliyah diharapkan secara sukarela menjadi seorang muslim. Menjadi seorang muslim hendaknya didasarkan kepada penerimaan dan kesadaran, bukan dengan paksaan atau tekanan.

Untuk mengenalkan dakwah pada anak usia dini membutuhkan kesabaran yang ekstra dengan memahami kondisi anak misalnya proses pertumbuhan kognitifnya yang masih dalam tahap pra operasional formal, sehingga membutuhkan metode dalam aplikasinya yang mudah difahami anak. Metode dalam mengenalkan dakwah pada anak melalui bernyanyi, tauladan, bermain peran, karya wisata, bersyair, dan berpidato.

Kita bukanlah anak-anak kita, sehingga pendidikan yang dulu pernah kita dapat dari orang tua kita tidaklah serta merta dapat diaplikasikan pula kepada anak-anak kita, karena zamannnya telah berbeda. Sebagaimana hadits yang diriwayatkan oleh Bukhori dan Muslim : "Didiklah anakanakmu, sebab mereka dilahirkan untuk hidup dalam suatu zaman yang berbeda dengan zamanmu." 


\section{DAFTAR PUSTAKA}

Ahmad, Amrullah, Dakwah Islam dan Perubahan Sosial, (Yogyakarta: Primaduta, 1983).

Departemen Agama RI, Alquran dan Terjemahnya, (Jakarta: Yayasan Penafsir dan Penterjemah Alquran, 1995).

H, Kirschenbaum, 100 Ways to Enhance Values and Morality in Schools and Youth Settings. (Massachusetts: Allyn \& Bacon, 1995).

Poerwadarminta, W.J.S., Kamus Umum Bahasa Indonesia, Edisi Ketiga, (Jakarta: Balai Pustaka, 2007).

R, Moeslichatoen, Metode Pengajaran di Taman Kanak-Kana,. (Jakarta: Rineka Ciipta, 1999).

Rasyid Ridha, Muh., Tafsir al-Manar, Juz IV (Kairo: al-Maktabat al-Qahirah, 1965).

Rosyad Saleh, Abdul, Manajemen Dakwah Islam, Cet. III, (Jakarta: Bulan Bintang, 1993).

Satibi Hidayat, Otib, Metode Pengembangan Moral dan Nilai-Nilai Agama,(Jakarta: Universitas Terbuka, 2000).

Suyanto,Slamet, Dasar-Dasar Pendidikan Anak Usia Dini, (Yogyakarta: Hikayat, 2005).

Siddiq, Syamsuri, Dakwah dan Teknik Berkhutbah , Cet. VI, (Bandung: alMa'arif, 1993).

Zuchdi, Darmiyati, Humanisasi Pendidikan (Kumpulan Makalah dan Artikel Tentang Pendidikan Nilai), (Yogyakarta: Program Pascasarjana UNY, 2003).

www.alhikmah.ac.id 